\title{
A Review of Preventive Health Care in Geriatrics through Ayurveda
}

\author{
Review Article
}

\section{Shanker Lal Burdak ${ }^{1 *}$, Nisha Gupta ${ }^{2}$}

1. PG Scholar, 2. Assistant Professor P.G. Department of Basic Principles, National Institute of Ayurveda, Jaipur-302002

\begin{abstract}
Ayurveda is basically the science of life and longevity. Ageing is a process of physical, psychological and social change in multi-dimensional aspects. According to the Ayurveda, ageing is outcome of kala or parinama. Vata dosha is the most important factor in the pathophysiology of ageing obviously because of its natural predominance at that stage of life. Ayurveda advocates an excellent approach for promotion of health, prevention of diseases and delaying the process of ageing with number of measures mentioned in svastha chatushka and rasayanadhyaya of charakasamhita, time to time panchakarma and various herbal drugs. Jarachikitsa or Rasayana in Ayurveda is a unique therapeutic methodology to delay ageing and to minimize the intensity of problems occuring in this degenerative phase of one's life. Prevention and management of health problems could help the elderly to improve quality of life and remain self dependant for their daily activities to maximum possible extent.
\end{abstract}

Keywords: Geriatrics, Ageing, Rasayana, Geriatrics in Ayurveda, Geriatric care

\section{Introduction}

Ayurveda gives top priority to geriatrics. The term geriatrics is derived Greek word, Geri - old age and iatrics care. It is the branch of medicine concerned with the care and treatment of elderly. The word geriatric has also a close link with the Sanskrit word jiryadi' which means degenerated. According to Ayurveda, human body consists of three doshas (vata, pitta and kapha), Saptadhatus (rasa, rakta, mamsa, medas, asthi, majja and shukra) and three malas (mutra purisha and sveda).(1) The dhaus get degenerated due to the body's

*Corresponding Author:

\section{Shanker Lal Burdak,}

PG Scholar,

P.G. Dept. of Basic Principles, National

Institute of Ayurveda, Jaipur-302002

Email id - drslburdak007@ gmail.com, burdakshankar2007@gmail.com

Contact No. - +919460045318 prolonged structural changes. During old age we cannot enhance the capacity of dhatus, but it can be protected and rejuvenated.

In Ayurveda the human body has been described as a living subject where the wear and tear is a continuous and perpetual phenomenon. Regeneration and degeneration go simultaneously right from the neonatal life to young age where growth and development occurs, after wards this process is altered and degeneration takes upper hand. As the age advances body becomes fragile, digestion and metabolism gets weakened and the body succumbs to various diseases.

Ageing is a process of physical, psychological and social change in multidimensional aspects. According to the Ayurveda, ageing is outcome of kala or parinama. Dosha dosha is the most important factor in the pathophysiology of ageing obviously because of its natural predominance at that stage of life. 
Ayurveda, the Indian traditional holistic health science has got the potential for prevention of diseases by promotion of health and management of diseases occurring in old age. Prevention and management of health problems could help the elderly to improve quality of life and remain self-dependent for their daily activities to maximum possible extent. Ayurveda has broad spectrum of preventing measures for combating the ageing process.

\section{Objectives:}

1) To understand the concept of ageing.

2) To understand and elaborate preventive measure in Geriatrics -

1) Daily regimen (Dinacharya)

2) Seasonal Regimens (Ritucharya)

3) Tripods of Life (Trayopastambha)

4) Samshodhana (Panchakarma)

5) Rasayana

\section{Material and Methods -}

This article is based on a review of Charakasamhita. Materials related to aging, Vaya, and other relevant topics as dinacharya, ritucharya, sadvritta and Rasayana etc. have been collected from Charakasamhita.

\section{Concept of Vriddhavastha (later stage of life)}

Vriddhavastha is the last part of the lifespan and is mainly characterized by degenerative changes. Aging refers to a multidimensional process of physical, psychological, and social change. The changes are always degenerative in nature.

(2) According to Ayurveda the lifespan of an individual is divided into three parts known as Vaya. These are Balavastha (childhood), which lasts up to the age of 16 years; Madhyavastha (young and middle age), which lasts from the age of 16 years to $60-70$ years; and Vriddhavastha or Jirnavstha (old age), which refers to the period after 60 or 70 years.(3) Thus, every person will pass through a period when various decaying changes will take place, and this time period is known as Vriddhavastha. This stage is characterized by decay in the body, Dhatu (various bodily tissues), perception power of the Indriya (sensory and motor organs), potency, strength, speech, various mental and cognitive functions (e.g., memory, intellect, reception, retention, analytic ability, etc.). During this phase there is predominance of vata dosha (one of the three physiological body factors). The major physical changes seen at this time are wrinkling of skin, graying of hair, baldness, and a diminishing ability to do physical work.(4) The diseases that complicate this stage are Kasa (cough), shvasa (asthma), and so on. $(5,6)$

Vriddhavastha may be of two types: Kalaja jara (if it manifests after the age of 60 - 70 years) or untimely. (7) Akalaja jara may result due to aggravation of dosha and pitta dosha. Therefore, excessive utilization of all the causes of vata-pitta aggravation may lead to untimely aging. Some instances are causes of rajayakshma (a syndrome with deficient immunity), carelessness regarding prescribed regimen of tryopstambha (diet, sleep, and coitus), and causes of ojokshaya (deficient immunity), excessive and single use of Amla, lavana, katu, tikta, and kashaya rasa in diet.

\section{Pathophysiology}

There are various theories regarding the pathophysiology of aging in modern medicine, but we will limit ourselves to the Ayurvedic point of view. Growth, development, and maintenance of the anatomy and physiology of the body is completely dependent on four factors: Kala (time), Svabhava (nature), ahara/diet (which should be excellent in the terms of nutrients), and vighata abhava absence of obstructive factors in the growth and development of the body.(8) Among 
these, diet is very important as it nourishes Dhatu and is responsible for the maintenance of compactness, strength, and formation of an excellent form of Dhatu. This excellent form of Dhatu reflects in the terms of Sara (absoluteness of body tissues), which makes a person look young and beautiful.(9) When the diet is defective in the terms of Gramya-ahara (a deficient and unplanned diet) and when the rules are not followed regarding diet as well as lifestyle (i.e., when there is indulgence in day sleep, daily coitus without Vajikarana (aphrodisiacs), daily alcohol drinking, excessive physical work, lack of exercise, mental and emotional fluctuations, etc.), then as indicated by Acharya Charaka in the second Pada (subchapter) of Rasayana (rejuvenation) there is vitiation of Tridosha, which leads to various progressive pathological changes due to improper utilization of the diet. These pathological changes include loss of compactness of the muscles, looseness of joints, vitiation of Rakta (blood), excessive production of Meda (fatty tissue), failure of Majja (marrow) accumulation in bones, failure of production of shukra (semen), and loss of Ojas (vital factor). This pathology leads to various symptoms; for example, no enthusiasm due to increase in sleep, drowsiness, and lethargy; the respiratory rate is increased; the person is unable to initiate and perform physical and mental work; the memory, intellect, and complexion deteriorate; and the person become susceptible to various types of diseases and fails to live out his complete lifespan.(10) When all these changes are produced according to Kala (time) and Svabhava (nature), it is known as Kalaja Vriddhavastha (natural aging). These changes can be slowed down and avoided and thus this stage may be prevented; if the changes have already manifested, they can be managed. When these changes are produced due to defective diet and lifestyle, Vriddhavastha begins earlier and it is then known as Akalaja
Vriddhavastha (untimely aging). It can be managed and treated. Kalaja Vriddhavastha can also be treated, but the measures that are described for it are very difficult to perform and impractical in the current era, and besides, the medicines that have been described for the treatment of Kalaja Vriddhavastha are either unavailable or are controversial.(11) However, in our opinion, it is possible to treat Kalaja Vriddhavastha, if the treatment principles are followed exactly as described in the texts.

\section{Preventive Measures :-}

Ageing is a deleterious, progressive, universal and thus far irreversible. Constant efforts have been made to understand the process of ageing and slow the process of ageing. The strategies mentioned in svastha catușa and Rasayanadhyaya of Charakasamhita can achieve and maintain arogya and târunya, ruling out the principle of 'shiryate iti shariram'.

\section{1) Daily regimen (Dinacharya)}

The Ayurvedic regimen of right living is designed for maintenance of health achievement of a long, healthy active life, providing relief from pain and disease thereby achieving satisfactory enjoyment of life and attainment of self-realization.

\section{* Time to wake up:}

Waking up in brahma muhurta (12) i.e. 'two hours before the sunrise', Brahma is knowledge, which is gained by reading. It is the time which is ideal for gaining of the knowledge. And also now a day, there is a lot of pollution in the environment and in the morning hours it will be clean without pollution. Along with the clean air, the pleasant atmosphere, absence of noise, the morning rays of the rising sun is very beneficial to the health. Sun is the god of health. Health is got from the sun. So, one should get 
up early in the morning before sunrise.

* Acamana means to wash, which will be done after cleaning the excreta, tears, sneezing, and after travelling. It will helpful for the digestion of food, and also evacuation of the bowel completely. (13)

* Danta dhavana \& Jihva nirlekhana (Cleansing of the mouth):

Cleansing of teeth and mouth should be practiced after every meal in addition to early morning and before going to bed. The soft brushes made out of twigs of khadira, karanja, nimba, arka, apamarga, etc. should be used for this purpose. Tongue and mouth should be cleaned by a long flexible strip of metal or plant material. Mouth should also be cleaned properly. It not only cleanses the teeth and tongue but also stimulates digestion, brings freshness and takes away the bad odor. But in modern age by using chemicals the pastes are going to be prepared. So those are not useful for the modern era to have a long life. (14)

* Ushahpana (Drinking Water):

Drinking water early in the morning according to one's capacity cleanses the body by enhancing the elimination of toxic wastes. (15)

* Bowels:

One should attend the nature's calls. Elimination of urine and faeces cleanse the body and cheers up the mind. (16)

* Gandusha and Kavala: It gives strength to mandible, clarity of mouth, lightness and clarity of sense organs. And also gives good taste. In modern era such items are prepared with chemicals, so one should avoid those chemical items. (17)

\section{* Dhumapana:}

Smoking is the procedure to take smoke through the nostril and then through the mouth. It gives benefits like lightness of the chest, throat, head, and liquefaction of the Kapha. (18) In modern era smoking is completely different and fashionable because they are taking the smoke through the mouth and leaving out through the nostril. And that cigarette contains nicotine like harmful things which will affect the lungs. So by smoking with these things instead of increasing the life span they will decrease the life span.

* Nasya:

Head is considered as the most important part of the body. So nose is the entry way for the head. It causes benefits like lightness of the head, proper sleep, and awakening, cure of diseases, clarity of organs, and pleasant mind. (19) In modern days nasal insufflations are there. So they are prepared from plant origin they are good for health.

* Eye Care:

Eyes should be cleaned with fresh water to prevent eye diseases and promote vision.(20) Also wash eyes with triphala water every day. Anjana should be used; it cleans the eyes, which makes them shine like the bright moon in clear sky. (21)

* Tambula Sevana (Betel Chewing): Chewing of betel leaves with small pieces of puga (Areca nut) and fragrant substances like cardamom, cloves, refreshes the mouth and enhance digestion.(22) Tobacco and tobacco preparations should be strictly avoided.

* Abhyanga (Oil Massage):

It is highly beneficial to massage whole body including scalp with oil 
everyday to prevent dryness of body and stiffness of joints due to ageing in elderly. For massaging, tila taila (sesame oil), sarshapa taila (mustard oil), narikela taila (coconut oil) or any medicated oils like Narayana taila may be used. Oil massage ensures softness and unctuousness of skin, free movement of joints and muscles; renders nourishment, improves peripheral circulation and eliminates metabolic wastes. By taking proper massage it delays aging, cures tiredness and dosha disorders, and improves vision, complexion, life, sleep. (23) And by doing padabhyanga, it provides strength and stability to feet, improves the vision and pacifies the dosha.(24) By doing śirobhyanga it prevents the balding, graying, hair fall, strengthens the hair root, and makes the hair long and black and it also nourishes the sense organs, softens the skin. (25)

* Karnatarpana (Ear Care): Ears should be nourishes by oil drops regularly to prevent ear related problems of old age like badhirya (deafness) or uchchaih shruti (partial deafness). (26) Ears wax should be cleaned water to prevent other ear problems and promote hearing.

* Udvartana: By doing this blood vessels become dilated and complexion in the skin is enhanced. Cures rashes, dosha diseases, enhances the strength of thighs, and provides the lightness.(27)

* Samvahana; Gentle massage enhances the affection, sleep, virility, avoids the Kapha and also improves the circulation.

* Vyayama (Exercise)

Regular exercise builds up stamina and resistance against disease, clears the channels of body (srotas) and increases efficiency of vital organs, and promotes appetite and digestion. (28) Daily physical activity can help to prevent heart disease and stroke by strengthening heart muscle, lowering blood pressure, raising HDL levels (good cholesterol) and lowering LDL levels (bad cholesterol), improving blood flow, and increasing heart's working capacity. Physical activity helps to reduce body fat by building or preserving muscle mass and improving the body's ability to use calories. When physical activity is combined with proper nutrition, it can help control weight and prevent obesity, a major risk factor for many diseases as diabetes, Hypertension and cardiac diseases by increasing muscle strength and endurance and improving flexibility and posture, regular exercise helps to prevent back pain. It helps for the controlling the blood sugar, reduces the risk of osteoporosis and cancer, helps for giving energy, reducing the stress, improves the sleep, to enhance mode of work and the selfesteem. Daily walking is the best exercise that can be advised to old people. (29)

* Snana (Bath)

Bathing enhances virility, longevity, strength, appetite, compactness and ojas, at the same time it cures tiredness, sweat and impurities of the body. It takes away the sleep, burning sensation, sweat, thirst and unpleasantness due to sweat. (30) After bath, one should wear clean clothes and smear the body with natural perfumes. One should have regular shaving, hair cut, clipping of nails etc.

\section{Dinacharya - Psychological Effects}

Regular physical activity can 
improve mood and the way one feel about himself/herself. Researchers also have found that exercise is likely to reduce depression and anxiety and help to manage stress. Bath with Luke warm water is advised after physical exercise for cleaning of body and by doing so, tiredness, sweating, drowsy and thirst vanishes whereas appetite, age and strength increases.

The Dinacharya makes one to lead a healthy and disciplined life. According to the latest studies in the field of medical science, people who stick to the daily routine are more fit than those, who do not have a particular time to perform their everyday activities. It is said that Dinacharya reduces the stress level to a great extent. In addition to this, the person's body is purified and detoxified.

\section{* Sadvritta}

It comes from two words "Sad" which means good and vrtta which means solution. It aims to develop the right balance between one's mind and body for the growth of a person. (31) People need specific codes that are gained by doing Sadvritta in increasing sattvika mind quality. A sound mental health is not just the absence of any mental disorders, but also the ability to keep up with the challenges one is encountering in late phase of his/her life. Mental health is as important as physical health in elderly persons.

\section{- Dhyana and Yoga therapy}

Means an attempt to unite individual consciousness with the cosmic divine or supreme consciousness. This is a strategy to totally integrate physical, mental, intellectual and spiritual aspects of human personality. Dhyana helps in "chitta vritti nirodha". (32) Both attempts ensure arogya to achieve the goal of life i.e. Dharma, Artha, Kama and Moksha. (33)

\section{* Pranayama}

It has a salutary effect on general health and vitality. Pranayama helps to procure oxygenated blood to various organs and body tissues and elimination of waste product in form of carbon dioxide. Pranayama helps to improve bio-energy and proper conjugation of respiratory and nervous system.

\section{2) Ritucharya}

This word is the combination of two words i.e. ritu meaning seasons and charya meaning routine (34) thus complete term meaning is routine which is to be followed in different seasons. Ayurveda focuses on living in tune with nature. It recognizes the intimate relationship between the individual and the environment. The existence and wellbeing of a person depends largely on the continuous adjustments and interactions with the external and internal factors of the environment. Ayurveda recognizes that seasonal changes have a profound effect on our health, and recommends many helpful suggestions for how one can adapt lifestyle to stay balanced in each season. Ayurveda made the personified specific suggestions because one lifestyle or diet cannot suit everybody as people have different constitutional make up. It maintains the climatic homologation in form of dosha samya (equilibrium) in different seasons to promote svasthavritta (preventive and social medicine) on which Ayurveda has laid a great stress since prevention is better than cure. 


\begin{tabular}{|c|c|c|c|}
\hline $\begin{array}{l}\text { Seaso } \\
\mathrm{n}\end{array}$ & $\begin{array}{l}\text { Ahara } \\
\text { (diet) }\end{array}$ & Vihara & $\begin{array}{l}\text { Purifica } \\
\text { tory } \\
\text { measure }\end{array}$ \\
\hline $\begin{array}{l}\text { Hema } \\
\text { nta \& } \\
\text { Śhishi } \\
\text { ra }\end{array}$ & $\begin{array}{l}\text { Madhur } \\
\text { a, Amla } \\
\text { and } \\
\text { Lavaṇa } \\
\text { Rasa, } \\
\text { nutritiou } \\
\text { s diet. }\end{array}$ & $\begin{array}{l}\text { Massage, } \\
\text { exercise, } \\
\text { woolen } \\
\text { blankets, } \\
\text { protectio } \\
\text { n against } \\
\text { cold. }\end{array}$ & - \\
\hline $\begin{array}{l}\text { Vasan } \\
\text { ta }\end{array}$ & $\begin{array}{l}\text { Laghu } \\
\text { and } \\
\text { Ruksha } \\
\text { Ahara } \\
\text { specially } \\
\text { Laja, } \\
\text { Canaka } \\
\text { (Bengal } \\
\text { grams). } \\
\end{array}$ & $\begin{array}{l}\text { Massage, } \\
\text { exercise, } \\
\text { fomentati } \\
\text { ons. }\end{array}$ & Vamana \\
\hline $\begin{array}{l}\text { Grish } \\
\text { ma }\end{array}$ & $\begin{array}{l}\text { Madhur } \\
\text { a, Laghu } \\
\& \\
\text { Snigdha } \\
\text { Dravya, } \\
\text { light in } \\
\text { digestion } \\
\text {. }\end{array}$ & $\begin{array}{l}\text { Seeta and } \\
\text { seasonal } \\
\text { fruits like } \\
\text { Amra } \\
\text { (mango), } \\
\text { Jambu } \\
\text { (Jamun); } \\
\text { cold air } \\
\text { and } \\
\text { wherever } \\
\text { possible } \\
\text { air } \\
\text { passing } \\
\text { through } \\
\text { Ushira } \\
\text { (khasa). }\end{array}$ & - \\
\hline $\begin{array}{l}\text { Varsh } \\
a\end{array}$ & $\begin{array}{l}\text { Kashya } \\
\text { and } \\
\text { Madhur } \\
\text { a Rasa; } \\
\text { Amla, } \\
\text { Lavana } \\
\text { Snehayu } \\
\text { kta } \\
\text { Dravya; } \\
\text { digestive } \\
\text { substanc } \\
\text { es; light } \\
\text { diet, } \\
\text { boiled }\end{array}$ & $\begin{array}{l}\text { Avoid } \\
\text { sleeping } \\
\text { on the } \\
\text { ground; } \\
\text { clear the } \\
\text { dirty } \\
\text { monsoon } \\
\text { water } \\
\text { from the } \\
\text { area } \\
\text { around. }\end{array}$ & Basti \\
\hline
\end{tabular}

\begin{tabular}{|c|c|c|c|}
\hline & $\begin{array}{l}\text { and } \\
\text { clean } \\
\text { water; } \\
\text { curd, } \\
\text { whey, } \\
\text { lemon; } \\
\text { Kshara } \\
\text { and } \\
\text { Kshara } \\
\text { preparati } \\
\text { ons. }\end{array}$ & & \\
\hline $\begin{array}{l}\text { Śarad } \\
a\end{array}$ & $\begin{array}{l}\text { Madhur } \\
\text { a, } \\
\text { Kashaya } \\
\text { Rasa; } \\
\text { Snigdha } \\
\text { Dravyas } \\
\text { specially } \\
\text { ghee and } \\
\text { milk; } \\
\text { sweets; } \\
\text { rice and } \\
\text { its } \\
\text { preparati } \\
\text { ons. }\end{array}$ & $\begin{array}{l}\text { To sit in } \\
\text { moon } \\
\text { light in } \\
\text { the first } \\
\text { quarter of } \\
\text { night, } \\
\text { exercise; } \\
\text { avoid } \\
\text { curd and } \\
\text { acrid diet } \\
\text { etc. }\end{array}$ & $\begin{array}{l}\text { Virecan } \\
a \quad \text { and } \\
\text { Blood- } \\
\text { letting. }\end{array}$ \\
\hline
\end{tabular}

3) Tripods of life (Trayopastambha):

In Ayurveda, Ahara (food), Nidra (sleep) and Brahmacarya (Controlled sex) are regarded as the three pillars or tripods of healthy living.(35) It is important for our body to be adjusted to timely intake of good quality and proper food, regular sleeping habits and controlled indulgence in sex in order to ensure long and healthy life. It is thus vital to have a regular systematic food and sleeping habit so that the body has a regularized automatic system of maintenance. It is even mandatory to maintain a balanced sex life and avoid extra indulgence worldly life. This practice of celibacy along with a proper daily regimen to only promotes life and preserves health but also give enrichment to the soul and other cognitive organs along with the mind which can prevent various ailments of old age. 


\section{Ahara (Dietetics / Ageing and Nutrition)}

Elderly people have different nutritional requirements compared to the normal adult population. With increasing age, people become more vulnerable to malnutrition for many reasons including arocaka (anorexia) due to ageing, medication, disease like smritinasha (dementia), manovasada (depression), stroke, kampadosha (Parkinson disease) and other neurological disorders, poor dentition, delayed gastric emptying, illfitting dentures, swallowing problems, oral infections, taste changes and diminished smell sensation. Older individuals tend to respond to thirst much less than the younger ones, predisposing to dehydration particularly in case of fever and diarrhea. Therefore fluid intake is necessary to replace physiological losses, better digestion and intestinal function and for renal clearance. There is no change in absorption of fats and carbohydrates, whereas vitamin $\mathrm{D}$ and calcium absorption is impaired, which leads to their deficiency. Calcium intake along with vitamin $D$ is necessary to prevent bone mineral loss in elderly. Diet containing dairy products, fish, legumes, nuts, eggs, etc. are full of vitamin $\mathrm{D}$ and calcium. In addition, organic calcium like pravala pishti, pravala pancamrita, kukkutandatvak bhasma and karpada bhasma etc. may be given as medication. Folic acid deficiency is more common in elderly.

Diet containing Fruits, roasted cereals like gram, peanuts, pulses etc. Sprouted cereals, Puffed rice, butter milk (mattha) are considered as healthy food items should be given to the elderly. It is needed to change our style of food as: Consume a diet rich in vegetables and fruits (all colored), avoid eating more high calorie fruits (mango, banana, jack fruit etc), whole fruit is better than fruit juice because it contains fiber. Vegetables which are green, reduces fat and blood sugar level. Stop or minimize alcohol intake, because alcohol is hollow calorie drink. And have sufficient water such as 3 to 3.5 lit/day. Prepare food by boiling, roasting, steaming, baking and avoid frying.

Following points may be considered while planning/ advising dietary and other life style regimen in all ages (especially in old age).

* The food should be tasty, nutritious, fresh and good in appearance

* Too spicy, salty and pungent food should be avoided

* It should neither be very hot nor very cold

* Liquid intake should be more frequent and in small amount

* Heavy food can be prescribed in a limited quantity

* Heavy food should not be given at night. The proper time for night meals is two to three hours before going to bed. After dinner, it is better to advice for a short walk.

* Heavy physical work should be avoided after meals

* Mind should be peaceful while eating

* Eating only whenever hungry and avoidance of over eating

* Inclusion of sufficient amount of vegetables and fruits in diet.

* Daily intake of vegetable soup and fruit juices

* Milk and ghee are the agryaushadha (drug of choice) of vardhakya (senility) (36). Hence their daily usage is advisable. Patient with hyperlipidaemia, ischemic heart disease, obesity these use in moderate quantity is essential.

Nishacarya (Night Regimen)

Nidra is one of the most important pillar of life. Sleeping is essential for us to live a balanced life. As we recognize sleeping when were charge our batteries. It is the 
physiological condition of the body, sense and motor organs and mind. When the brain is tired and exhausted, our sense organs get distracted and lose focus in what one is doing. (37) Before going to sleep, relax and feel comfortable about self. Think of a religious message before going to sleep. Since sleeping is also a way to repair damaged cells.

\section{4) Panchakarma}

Ayurveda heals through purification and rejuvenation therapies. These therapies aim at promoting longevity in life by guiding the individual in the prevention of disease. (38) Panchakarma therapy, which is effective in cleansing of body toxins, plays a pivotal role in this. The detoxification process is necessary for eliminating the toxic waste from the organic system and thereby assuring smooth and natural organic function. It takes the responsibility of the purification and balancing the complete organic system that can ensure natural wellbeing as well as health. So the benefits that one experience through Panchakarma should not be considered in regard to treatment of some particular diseases or disorders, but rather in regard to rendering total health benefits that would naturally combat any disorder or disease.

\section{5) Rasayana (rejuvenation)}

The strength of Ayurveda in the context of Geriatric care is Rasayana therapy. Rasayana stands as an answer in preventing premature ageing and to solve the problems due to ageing; it also ensures healthful longevity including mental health and resistance against various geriatric disease conditions.(39) The observance of dietetics, rules of hygiene are essential for the success of treatment prescribed for healthy longevity of life and rejuvenation.

\section{Why Rasayana in Geriatrics:}

Every man scare, a multifactorial and i nevitable biological phenomenon is ageing. The proportion of elderly people is constantly increasin $\mathrm{g}$ along with age related diseases. Even though it is impossible to adopt all the things certain changes in life style like practice of rejuvenating diet, medicine, yoga will c ertainly help to prevent many diseases as well as to overcome many problems related to ag eing.

Mode of action of Rasayana drugs:

Some drugs like Ashvagandha and Shiljatu nullify the effects of stress and drugs like Gambhari improve nitrogen balance and promote tissue building. Guggulu clears the channels and enhances the nutrition to all tissues and cells. Amalaki and Bala contain antioxidants which help in the scavenging

of free radicals released. Achara Rasayana acts as psycho immune modulator reduces stress and thus prevents the release of $f$ ree radicals.

\section{Achara}

\section{Rasayana advantages or benefits:}

Rasayana chikitsa is incomplete without adopting Achara Rasayana; Of course one who has admitted Achara Rasayana is most suitable person to undergo Rasayana chikitsa observing Achara Rasayana itself bring many bimolecular level Rasayana effects. The complete positive and promotive health care is achieved through Achara Rasayana. (40)

The whole concept of Rasayana therapy is oriented to enhance quality of health in an individual which one of the two prime mottos of Ayurveda treatments. 
Now a day's prevention of the diseases is achieved by immunization specifically against the each disease but the number of the diseases is so much that practically it is not possible to immunize a person against all the diseases. On the other hand the concept of Rasayana seems to increase the general immunity so that one can live a long span of youthful life free from the diseases. It may provide an umbrella against the diseases and ageing by promoting the physical and mental health. All these points generate an idea about the Ayurveda believes in promoting the general immunity of a person so that he can fight out any type of disease.

There are specific Rasayana for different age groups, which help in restoring the loss of specific bio-values of respective ages. Regular use of ghee, milk, fruits and vegetables in diet acts as Rasayana.

\section{Discussion}

Ayurveda also emphasizes on an ideal method of healthy living. A special section of Ayurveda, Svasthavritta deals with the science of health and the code for a healthy conduct. 'Svasthavritta' which literally means 'the regime of abiding in one 'sown nature' is an individual's guide to the path of healthy and long life. In Ayurveda, one's body is regarded as a temple and thus, several ways are prescribed for keeping it healthy and young life long. The principles of maintaining a proper wellbeing of the body and mind are in corporate in Ayurveda in form of Dinacharya, ritucharya, balanced diet and the observance of personal, moral, seasonal and spiritual conduct. These ways of living helps in healthy functioning of five sensory organs, nervous system along with other vital organs of the body. Other than this Ayurveda also prescribes Sadvritta. The right ways of living i.e. following good mental, social, religious, personal and moral conduct which may help to overcome the feeling of stress and fatigue in fast pace life. The stress is a major factor responsible for various ailments of old age. The process of ageing and process of disease are not only because of somatic changes but also due to psycho neuro-humoral changes. The Rasayana therapy bestows human kind by proving them disease free long life and helps in uplifting the quality of their life, by manipulating ageing process and disease process.

Remarkably modern pharmacology a nd clinical medicine are actively conductin $\mathrm{g}$ series of studies on anti ageing drugs, disorder of senile stage of human body and aging process, the vast knowledge of Indian medicine, the science of life itsel $\mathrm{f}$, is competent source of potentials in regard the concepts, principles, drugs and medicin e including the management of ageing disorders, preservation of health, compreh ensive fitness of body and mind and rejuve nation of life with longevity. Thus the anti ageing herbal drugs have wide prospects in the world prospective.

\section{Conclusion}

A healthy mind is as important as healthy body. Sattvika ahara is considered to be the best hitakara (wholesome), pathyakara (compatible) diet. It is a vegetarian diet containing non-oily, nonspicy articles which are easily assimible (satmya) e.g. milk, rice, green vegetables, certain fruits etc. Ayurveda adopts Sattvavajaya chikitsa (non-drug psychotherapies) that includes various codes of conduct (Achara Rasayana) for maintenance of better mental health and to prevent various mental disorders. Old age is an undesirable and inevitable phase of human life. The life science of Ayurveda explains that, process of senescence begins naturally (svabhavoparamavada) under the influence of time (kala). Though the disturbance in the equilibrium in all the three doshas occurs during old age, there is 
dominance of Vata dosha in this age. Ancient Ayurvedic scholars have clearly mentioned that during old age quantity and quality of all the Dhatu decreases. The combination of dominant state of Vata dosha and deterioration of rasadi Dhatu, srotas and agni are responsible for the various degenerative changes and process of decay in the body. Ayurveda holds that there is no magical remedy or short cut for healthy living. Instead, strict and staunch regulation of the Acharyas, the principles of healthy lifestyle which include a proper routine regarding ahara, vihara and Acharas based on hetu (Material cause), kala (Season) and desha (Habitat) are the only ways for healthy living. Ayurveda defines the healthy state as: 'A person, whose somatic and psychic humors are in equilibrium, digestion is uniformly healthy, with normal functioning of the fundamental tissues of the body and body wastes, accompanied by the processes of the soul, cognitive organs and the mind, is said to be a healthy person.' Hence geriatric care warrants management of Agni, Ama and Oja (the essence of all Dhatus) at biological level. Rasayana drugs which compensates the age related bio-losses in the body and provide rejuvenating effect, act primarily at the level of Rasa Dhatu, Agni and Srotas. In nutshell we can say that by combining Rasayana therapy, wholesome diet, Dinacharya, ritucharya, Sadvritta, yoga and time to time panchakarma are likely to develop an effective package for geriatric care today.

Therefore, these strategies indicated by Ayurveda in respect of health care of people in all phase of life especially ageing population should be religiously followed by letter and spirit. All these strategies can contribute in a big way for healthy and happy old age.

\section{References}

1. Sushruta, SushrutaSamhita with Nibandha Sangrha Commentary of Dalhanacarya, edited by Vidya Yadavji
Trikarmaji Acharya, Chaukambha Surbharti Prakashan, Varanasi, Edition $7^{\text {th }}, 2008$, Sutrasthan 15 verse 3, p. 67.

2. Park K., Park's Textbook of Preventive and social medicine, Banarsidas Bhanot Publishers, Jabalpur; Edition $19^{\text {th }}, 2008$, p.434.

3. Agnivesha, CharakSamhita With Ayurveda Dipika Commentary Of Chakrapani Datta, Ed. Acharya Yadavji TrikarmaJi, Chaukhambha Surbharti Prakashan, Varanasi. Edition $7^{\text {th }}, 2002$, Vimanasthana Chapter 8,verse 122, p. 280

4. (Downloaded on January $6^{\text {th }} 2010$ ). http://www.skincarephysicians.com/agi ngkinnet/basicfacts.html

5. Agnivesha, CharakSamhita With Ayurveda Dipika Commentary Of Chakrapani Datta, Ed. Acharya Yadavji TrikarmaJi, Chaukhambha Surbharti Prakashan, Varanasi. Edition $7^{\text {th }}, 2002$, SutraSthana Chapter 8,verse 122, p. 280

6. Sushruta, SushrutaSamhita with Nibandha Sangrha Commentary of Dalhanacarya, edited by Vidya Yadavji Trikarmaji Acharya, Chaukambha Surbharti Prakashan, Varanasi, Edition $7^{\text {th }}, 2008$, Sutrasthan 35 verse 29, p. 155.

7. Sushruta, SushrutaSamhita with Nibandha Sangrha Commentary of Dalhanacarya, edited by Vidya Yadavji Trikarmaji Acharya, Chaukambha Surbharti Prakashan, Varanasi, Edition $7^{\text {th }}, 2008$, Sutrasthan 24 verse 7, p. 114.

8. Agnivesha, CharakSamhita With Ayurveda Dipika Commentary Of Chakrapani Datta, Ed. Acharya Yadavji TrikarmaJi, Chaukhambha Surbharti Prakashan, Varanasi. Edition $7^{\text {th }}, 2002$, Sharirasthana Chapter 6,verse 12, p.68

9. Sushruta, SushrutaSamhita with Nibandha Sangrha Commentary of Dalhanacarya, edited by Vidya Yadavji Trikarmaji Acharya, Chaukambha Surbharti Prakashan, Varanasi, Edition $7^{\text {th }}, 2008$, Sutrasthana 35 verse 18 , p. 114. 
10. Agnivesha, CharakSamhita With Ayurveda Dipika Commentary Of Chakrapani Datta, Ed. Acharya Yadavji TrikarmaJi, Chaukhambha Surbharti Prakashan, Varanasi. Edition $7^{\text {th }}$, 2002, CSthana Chapter 1, Pada 2, verse 3, p.68

11. Sushruta, SushrutaSamhita with Nibandha Sangrha Commentary of Dalhanacarya, edited by Vidya Yadavji Trikarmaji Acharya, Chaukambha Surbharti Prakashan, Varanasi, Edition $7^{\text {th }}, 2008$, Sutrasthan 24 verse 7, p. 114.

12. Vagbhatta, Ashtangasamgraha with Shashilekha Commentary of Acarya Indu, Edited by Shivprasad Sharma, Chowkhambha Sanskrit Series office, Varanasi, Edition $3^{\text {rd }}, 2012$, Sutrasthan 3 verse 2, p. 16.

13. Vagbhatta, Ashtangasamgraha with Shashilekha Commentary of Acarya Indu, Edited by Shivprasad Sharma, Chowkhambha Sanskrit Series office, Varanasi, Edition $3^{\text {rd }}$, 2012, Sutrasthana 3 verse 4, p. 17.

14. Agnivesha, CharakSamhita With Ayurveda Dipika Commentary Of Chakrapani Datta, Ed. Acharya Yadavji TrikarmaJi, Chaukhambha Surbharti Prakashan, Varanasi. Edition $7^{\text {th }, ~ 2002, ~}$ SutraSthana Chapter 5,verse 71-75, p. 42

15. http://sa.wikibooks.org/wiki/आनन्दकन्द_1. 17 ; uṣaḥpānaRasayanam, verse 8.

16. Vagbhatta, Ashtangasamgraha with Shashilekha Commentary of Acarya Indu, Edited by Shivprasad Sharma, Chowkhambha Sanskrit Series office, Varanasi, Edition $3^{\text {rd }}, 2012$, Sutrasthana 3 verse 3, p. 16.

17. Agnivesha, CharakSamhita With Ayurveda Dipika Commentary Of Chakrapani Datta, Ed. Acharya Yadavji TrikarmaJi, Chaukhambha Surbharti Prakashan, Varanasi. Edition $7^{\text {th }}$, 2002, SutraSthana Chapter 5, verse 78-80, p. 42.

18. Agnivesha, CharakSamhita With Ayurveda Dipika Commentary Of Chakrapani Datta, Ed. Acharya Yadavji
TrikarmaJi, Chaukhambha Surbharti

Prakashan, Varanasi. Edition $7^{\text {th }}$, 2002,

SutraSthana Chapter 5,verse 30-32, p.40

19. Agnivesha, CharakSamhita With Ayurveda Dipika Commentary Of Chakrapani Datta, Ed. Acharya Yadavji TrikarmaJi, Chaukhambha Surbharti Prakashan, Varanasi. Edition $7^{\text {th }}, 2002$, SutraSthana Chapter 5,verse 46-62, p.41

20. Sushruta, SushrutaSamhita with Nibandha Sangrha Commentary of Dalhanacarya, edited by Vidya Yadavji Trikarmaji Acharya, Chaukambha Surbharti Prakashan, Varanasi, Edition $7^{\text {th }}, 2008$, CikitsaSthana 24 verse $15-17$, p. 487.

21. Agnivesha, CharakSamhita With Ayurveda Dipika Commentary Of Chakrapani Datta, Ed. Acharya Yadavji TrikarmaJi, Chaukhambha Surbharti Prakashan, Varanasi. Edition $7^{\text {th }}$, 2002, SutraSthana Chapter 5, verse 14-17, p.3839.

22. Agnivesha, CharakSamhita With Ayurveda Dipika Commentary Of Chakrapani Datta, Ed. Acharya Yadavji TrikarmaJi, Chaukhambha Surbharti Prakashan, Varanasi. Edition 7 th, 2002, SutraSthana Chapter 5,verse 76-77, p.42

23. Agnivesha, CharakSamhita With Ayurveda Dipika Commentary Of Chakrapani Datta, Ed. Acharya Yadavji TrikarmaJi, Chaukhambha Surbharti Prakashan, Varanasi. Edition $7^{\text {th }}, 2002$, SutraSthana Chapter 5,verse 85-89, p.42

24. Agnivesha, CharakSamhita With Ayurveda Dipika Commentary Of Chakrapani Datta, Ed. Acharya Yadavji TrikarmaJi, Chaukhambha Surbharti Prakashan, Varanasi. Edition $7^{\text {th }}, 2002$, SutraSthana Chapter 5, verse 90-92, p.4243.

25. Agnivesha, CharakSamhita With Ayurveda Dipika Commentary Of Chakrapani Datta, Ed. Acharya Yadavji TrikarmaJi, Chaukhambha Surbharti Prakashan, Varanasi. Edition $7^{\text {th }}$, 2002, SutraSthana Chapter 5, verse 81-83, p.42. 
26. Agnivesha, CharakSamhita With Ayurveda Dipika Commentary Of Chakrapani Datta, Ed. Acharya Yadavji TrikarmaJi, Chaukhambha Surbharti Prakashan, Varanasi. Edition $7^{\text {th }}$, 2002, SutraSthana Chapter 5,verse 84, p.42.

27. Vagbhatta, Ashtangasamgraha with Shashilekha Commentary of Acarya Indu, Edited by Shivprasad Sharma, Chowkhambha Sanskrit Series office, Varanasi, Edition $3^{\text {rd }}$, 2012, Sutrasthana 3 verse 39, p. 21.

28. Agnivesha, CharakSamhita With Ayurveda Dipika Commentary Of Chakrapani Datta, Ed. Acharya Yadavji TrikarmaJi, Chaukhambha Surbharti Prakashan, Varanasi. Edition $7^{\text {th }}$, 2002, SutraSthana Chapter 7,verse 32, p.50.

29. Sushruta, SushrutaSamhita with Nibandha Sangrha Commentary of Dalhanacarya, edited by Vidya Yadavji Trikarmaji Acharya, Chaukambha Surbharti Prakashan, Varanasi, Edition $7^{\text {th }}, 2008$, CikitsaSthana 24 verse $80, p$. 490.

30. Agnivesha, CharakSamhita With Ayurveda Dipika Commentary Of Chakrapani Datta, Ed. Acharya Yadavji TrikarmaJi, Chaukhambha Surbharti Prakashan, Varanasi. Edition7th, 2002, SutraSthana Chapter 5, verse 93-94, p.43.

31. Agnivesha, CharakSamhita With Ayurveda Dipika Commentary Of Chakrapani Datta, Ed. Acharya Yadavji TrikarmaJi, Chaukhambha Surbharti Prakashan, Varanasi. Edition $7^{\text {th }}$, 2002, SutraSthana Chapter 8,verse 18, p.58

32. Patanjali, PatanjalYogasutram with Bhojavriti Hindi Tika by Beena Agrawal, Jagdish Sanskrit Pustakalya, Jaipur. Edition $1^{\text {st }}$, 2008, Samadhipada, verse 2, p. 7.

33. Agnivesha, CharakSamhita With Ayurveda Dipika Commentary Of Chakrapani Datta, Ed. Acharya Yadavji TrikarmaJi, Chaukhambha Surbharti Prakashan, Varanasi. Edition $7^{\text {th }}$, 2002,
SutraSthana Chapter 1,verse 15, p.6.

34. Agnivesha, CharakSamhita With Ayurveda Dipika Commentary Of Chakrapani Datta, Ed. Acharya Yadavji TrikarmaJi, Chaukhambha Surbharti Prakashan, Varanasi. Edition $7^{\text {th }}, 2002$, SutraSthana Chapter 6, verse 4-48, p.4448.

35. Agnivesha, CharakSamhita With Ayurveda Dipika Commentary Of Chakrapani Datta, Ed. Acharya Yadavji TrikarmaJi, Chaukhambha Surbharti Prakashan, Varanasi. Edition 7 th, 2002, SutraSthana Chapter 11,verse 35, p.74.

36. Agnivesha, CharakSamhita With Ayurveda Dipika Commentary Of Chakrapani Datta, Ed. Acharya Yadavji TrikarmaJi, Chaukhambha Surbharti Prakashan, Varanasi. Edition $7^{\text {th }}, 2002$, SutraSthana Chapter 25,verse 40, p.132.

37. Agnivesha, CharakSamhita With Ayurveda Dipika Commentary Of Chakrapani Datta, Ed. Acharya Yadavji TrikarmaJi, Chaukhambha Surbharti Prakashan, Varanasi. Edition 7th, 2002, SutraSthana Chapter 21,verse 35, p.118.

38. Agnivesha, CharakSamhita With Ayurveda Dipika Commentary Of Chakrapani Datta, Ed. Acharya Yadavji TrikarmaJi, Chaukhambha Surbharti Prakashan, Varanasi. Edition $7^{\text {th }}$, 2002, SutraSthana Chapter 16,verse 18-19, p.97.

39. Agnivesha, CharakSamhita With Ayurveda Dipika Commentary Of Chakrapani Datta, Ed. Acharya Yadavji TrikarmaJi, Chaukhambha Surbharti Prakashan, Varanasi. Edition 7th, 2002, Cikitsasthana Chapter 1, Pada 1, verse 78, p.376.

40. Agnivesha, CharakSamhita With Ayurveda Dipika Commentary Of Chakrapani Datta, Ed. Acharya Yadavji TrikarmaJi, Chaukhambha Surbharti Prakashan, Varanasi. Edition $7^{\text {th }}, 2002$, Cikitsasthana Chapter 1, Pada 4, verse 30-35, p.388. 